This is the accepted version of an article that will be published by Taylor and Francis in a Special Issue on Institutional Function and Credibility in the Journal of Peasant Studies: http://www.tandfonline.com/loi/fjps20\#.VyiniqMrLow

Accepted version downloaded from SOAS Research Online: http://eprints.soas.ac.uk/22364/

\title{
Rethinking Labour Market Institutions in Indian Industry: Forms, Functions and Socio-historical Contexts*
}

\author{
Satoshi Miyamura ${ }^{\dagger}$ \\ Department of Economics, SOAS, University of London, UK
}

\section{Abstract}

The emerging literature on institutional functionalism opens opportunities for historically- and socially-sensitive analysis of institutions, especially if it is complemented by a material understanding of institutions and their location within the wider social structure. This paper engages constructively with the 'credibility' thesis in institutional economics by developing an alternative materialist conception of labour market institutions (LMIs) and applies it to the debates on the Indian industry. Empirical observations collected from field research in various industrial sites in India show that changes to institutional forms have almost always involved labour unrest and conflict, but not always in accordance to the alleged form-function relations. The credibility thesis opens a way for debates on LMIs to move away from the central focus on their forms by evaluating the extent to which institutions are contested within specific socio-historical contexts. Also, the alternative conception suggests that labour, capital and the state may have perspectives on functions of LMIs that may not always coincide, which relate to different types of development. This is of particular interest in the context of India where the on-going policy debates on labour market reforms have primarily focused on 'form' variables. The implication is that the ongoing debates in India focusing on policies that attempt to engineer changes to forms of LMIs may be misguided and ineffective.

Keywords: word; institutional functions; labour market institutions; labourmanagement relations; trade unions; collective bargaining; India

\footnotetext{
* The fieldwork for this research was assisted by Arpit Gaind, Joy Karmakar and Pankaj Waghmare. I would like to thank participants at the Historical Materialism World Development Research Seminar; Economics Department Seminar, SOAS (London); and the 44th Annual South Asia Conference (Madison, Wisconsin), where earlier versions of this paper were presented. In particular, I am indebted to Liam Campling, John Echeverri-Gent, Ben Fine, Peter Ho, Jonathan Pattenden, and Helena Pérez Niño for their comments on earlier drafts. The usual disclaimers apply.

†Email:sm97@soas.ac.uk
} 
Subject classification codes: J5 (Labor-Management Relations, Trade Unions, and Collective Bargaining) 


\section{Rethinking Labour Market Institutions in Indian Industry: Forms, Functions and Socio-historical Contexts}

\section{Introduction}

Amendments to labour laws and modifications of trade unionism have been central to the debates on labour market reforms in India over the past three decades. There is a general recognition that the prevailing forms of these institutions need to be transformed, albeit with disparate opinions on the direction and content of such reforms. Proponents of labour market flexibility have argued for the removal or weakening of employment protection laws, decentralisation of collective bargaining institutions and reducing the roles played by political parties and external agents, including the state, in mediating industrial relations (for example, see GoI 2002; for further discussion, see Miyamura 2012). Despite the protestation by trade unions, civil society organisations and academics, the governing Bharatiya Janata Party (BJP) is currently proposing to introduce various measures to allow greater number of firms to operate outside the coverage of many labour legislations, and to make it more difficult for trade unions to be formed and recognised as representative agents (Deakin and Haldar 2015; Lerche 2015).

In addition to the standard arguments in favour of flexible labour markets that focus on growth, investment and employment generation, a variant of the Indian debate also points to possible effects of these labour market reforms in creating more harmonious labour-management relations. For example, Anant (2009: 195-200) has suggested that instead of trade unions and the state, 'there is a need to return to trust-based mechanisms' and 'social capital' in improving dispute resolution. The BJP, in its election manifesto, declared labour as the 'pillar of our growth', and suggested labour law reforms as one of the means to promote a 'harmonious relationship between labour and the industry' and to encourage them to embrace the concept of 'industry family' (BJP 2014: 31). The government's slogan of 'Make in India' necessitates 'disciplined' labour to be employed smoothly by foreign investors the country is attempting to attract.

This paper questions the premise assumed in these debates that once implemented, reformed institutions would perform in a predetermined and desired manner. It does so 
by engaging constructively with emerging approaches to 'institutional functionalism', in particular the 'credibility' thesis, as expounded in this special issue. As discussed in Section 1.1, labour (power) as commodity is distinct in its fundamental indeterminacy, and therefore it is of particular interest to evaluate the applicability of this thesis to the labour market. This paper is the first explicit attempt to explore the scope of the credibility thesis in the context of labour market institutions (LMIs). It also employs statistical technique previously unused for LMIs analysis to examine the thesis using empirical observations drawn from a long-term fieldwork on labour-management relations in Indian manufacturing industry between 2001 and 2014. It is argued that the credibility thesis allows the debates on LMIs to move away from the central focus on their forms by evaluating the extent to which institutions are contested within specific socio-historical contexts. Also, its focus on conflicts and contestations over LMIs highlights the importance of evaluating the forms and functions of these institutions in a context-sensitive manner, most importantly within the social and historical specificity in industrial development and social structure. The latter emphasis is derived from a materialist conceptualisation of LMIs as means to regulate the specific social relations of production. This alternative approach to LMIs, and the 'functionalist' approach more generally, are evaluated in light of debates around the nature of development, especially Selwyn's (2014) proposition for a 'labour-centred development'.

The remainder of the paper proceeds as follows. Section 1 discusses theoretical developments in approaches to LMIs and examines the scope of the credibility thesis as a framework for understanding institutional diversity and change in labour markets. The meaning of institutions, their forms and functions are re-examined, and an alternative materialist conception of LMIs is proposed.

Section 2 outlines the methodology employed in data collection and discusses contexts for the empirical analysis of this paper. This is followed by Section 3, where a descriptive statistic technique is used to map out broad formal characteristics of LMIs observed in the empirical data.

The resulting 'mapping' of LMIs is interpreted and discussed in Section 4. Section 4.1 compares patterns of LMIs in 'traditional sector' units in Kolkata and Mumbai, while Section 4.2 does the same for the 'modern sector'. Through these observations, the scope for the credibility thesis is discussed. Section 4.3 then draws on selected cases of 
institutional change to discuss factors underlying the diversity and dynamics of LMIs. Through the discussion in Section 5 the paper concludes.

\section{Theoretical approaches to labour market institutions (LMIs)}

In this Section, an alternative materialist framework for institutional analysis of labour markets is developed. In order to do so, it would be useful to discuss what is meant by LMIs and what their forms and functions mean.

\subsection{Rethinking LMIs}

Mainstream economics have tended to conceive institutions as dichotomous to markets: thus it refer to a whole range of formal and informal social arrangements from property rights and laws to normative rules and customs. The concept of LMIs more or less follows from this premise. For example, Saint-Paul $(2000,1)$ characterises LMIs 'as a set of institutions that restrict the ability of private parties to freely set quantities and prices,' while Nunziata $(2003,6)$ defines them as 'the set of rules, regulations, enforcement laws and organizational patterns governing the labour market'.

Note that orthodox neoclassical economics models labour markets as mechanism for smooth matching of labour supply and demand, and for the efficient allocation of labour services to productive sectors. In this sense, those debating LMIs can already be differentiated from this orthodoxy, where there is not room for LMIs. Nevertheless, the mainstream conception of LMIs is primarily focused on applying price theories to the exchange of labour (power or effort), and evaluate their efficiency or welfare implications. Furthermore, LMIs as 'rules' that govern labour markets is ahistorical and does not specify which socio-economic relations are to be prioritised in examining whether or not, and how, markets function differently (Miyamura 2012, 99-102).

In contrast, this paper proposes an alternative materialist conception of LMIs focused on how social relations of production are regulated, and which is sensitive to particular historical and social contexts in which labour markets operate. In order to do so, it is necessary to start with features of capitalist society as being characterised by conflictual social relations, in essence, between capital and wage-labour (Marx 1973: 100-108). Of course, in practice class compromise can arise, and indeed, collective bargaining can be understood as a negotiation process for profits to be 'shared' with labour. Nevertheless, 
capital-labour relations are necessarily conflictual because the production and appropriation of surplus-value is an appropriation of part of the product of the labour of others (Croix 1981: 43).

Also, although capital-labour relations often involve a variety of social and political expressions, including ethnicity and gender, the essence of capitalist social relations is an 'economic' conflict over the realisation of the labour power, due to its fundamental indeterminacy (Smith 2006; Thompson and Smith 2009). That is, the extent to which labour power is extracted cannot be predetermined prior to the production process, and therefore systems of management as well as bargained consent from labour are required. In this context, the role of LMIs can be interpreted more explicitly as means to regulate the structural conflict in the social relations of production. Note that what a 'regulation' of the relations means and what mode it takes are to be empirically worked out by examining the historically- and socially-specific patterns of capitalist development, as shall be discussed for cases in India in Section 4.

The rest of this paper will focus on collective bargaining institutions, in particular procedures for collective bargaining, and formations of trade unionism and other labour organisations. These, along with other institutions governing Indian labour markets, such as patriarchy and caste, are institutional conditions for extraction of surplus value and accumulation to take place, or the social structure of accumulation (Gordon, Edwards and Reich 1982; Harriss-White 2003: 119).

\subsection{Postulated form-function relations in LMIs}

Given the mainstream conception, the focus of much of the literature has been on identifying the 'right' forms of LMIs, which hinder the market mechanism less, and promote employment and productivity growth. Also, in many of the existing models, institutional functions are assumed to follow immediately from their forms. Thus, Freeman (1993) describes the traditional debates on LMIs to have been between the 'distortionists' who claim that the presence of labour laws or trade unions is necessarily harmful to efficiency and productivity due to their interference with the functioning of labour markets (Agarwala 1983; Fallon and Lucas 1991, Mangel, DeLorme and Kamerschen 1994; amongst others) and 'institutionalists' associating LMIs with potentially value-enhancing effects (Freeman and Medoff 1984; Calmfors and Driffill 
1988; Standing 1992). In particular, Calmfors and Driffill (1988) propose a humpshaped model to articulate that highly centralised or highly decentralised bargaining structures are less likely to encourage wage militancy by unions compared to intermediately centralised ones. Similarly, Pencavel (1995) suggests that trade unions affiliated to political parties are more likely to see their bargaining strategies detached from 'dealings with the employers and the workers they represent' (p. 3).

In the Indian debate, GoI (2002) has recommended weakening of employment protective clauses in legislation and removal of party-links in trade unions organisations as means to increase formal employment and raise productivity. Interestingly, Teitelbaum (2011) has countered studies such as Besley and Burgess (2004) by arguing that employment protective legislation and party-affiliated unionism strengthen the ability of the state to manage and 'restrain' labour militancy, and thereby can improve productivity and employment growth, but nevertheless remaining within the same causal logic of linking forms of LMIs to functions.

\subsection{Credibility thesis in LMIs}

There have been recent attempts within institutional economics, including the contributions to this special issue, to shift the analytical focus away from the fixation on institutional forms to discuss how they function. A variant of this 'functionalist' approach to institutional theory ${ }^{3}$ is the 'credibility' thesis, which Ho $(2014,16)$ has defined as 'the perception of endogenously, autonomously shaped institutions as a common arrangement'. In highlighting 'the endogeneity of credibility', Grabel (2000, 2; 11) considers roles played by 'class conflict, and the distribution of income, wealth and political power' in shaping the credibility of policies and institutions. By doing so, this approach focuses on what functions existing institutions and property rights fulfil as a way to explain their emergence and persistence.

In the context of LMIs, the research agenda proposed by the credibility thesis focuses the analysis and debates on the varied and dynamic ways in which prevailing collective

\footnotetext{
${ }^{3}$ Note that the 'functionalist' approach discussed here are to be differentiated from selfequilibrating systemic model of functionalism in sociology.
} 
bargaining arrangements and labour organisations are supported or contested by bargaining agents, and how these conflicts are managed at a given time and space (Ho 2014: 18). Thus, instead of the distortionist-intitutionalist debate on whether unionisation is harmful or conducive for the functioning of labour markets, the present research will examine conditions under which trade unions of various types and other labour organisations persist or are overthrown. It will not take for granted that collective bargaining at industry-level or party-affiliation of unions encourage or restrain labour militancy, but rather appraise circumstances under which they do so. Thereby the credibility thesis contends that institutional analysis should refrain from passing moral, theoretical and political judgements on institutional forms.

At the same time, moral and political perspectives are important in evaluating functions of LMIs. Given the alternative conception of LMIs in Section 1.1 as means to regulate the social relations of production, functions of LMIs differ depending on who's perspective on which institutional functions are to be evaluated. Firstly, given the conflictual nature of their relations, functions of LMIs are different for capital and labour. For capital, the function of LMIs as part of social structures of accumulation is to create and maintain stable conditions for the labour-power employed to be fully utilised in the production process. But this necessarily implies subjugation, however subtle or consented, by capital of labour, who in turn may resist extraction of labour power by demanding greater share of profits, shortening of the working day, or curbing the intensification of the labour process. Secondly, capital and labour may not respectively be a single agent in practice. Those in managerial classes may have different interests to be mobilised through LMIs depending on their role in the organisation. Similarly, interests of trade union officials may not fully coincide with rank-and-file workers, and moreover unionists at different levels of the organisation may also have different interests (Bhowmik 2006: 93). Finally in a capitalist society, capital-labour relations interact and are articulated with the state in complex ways, with competing interests differentiated and alliances forged in a temporary and spatiallyspecific ways (Bensaïd 2002: 111-2).

Thus, in order to understand the diversity and dynamics of LMIs, it becomes important to specify for whom the function of institutions are accepted or contested. This is a question unaddressed in the mainstream ahistorical conception of LMIs, but one that can be opened up through the credibility thesis. It is important to also note that the 
importance of moral and political perspectives reflects different conception of development. In mainstream development economics, labour is treated as commodity input for growth and economic transition. On the face of it, capital's perspective on the function of LMIs as regulating labour relations to maintain conditions for production to take place appear to be consistent with this conventional idea of economic development, even if the process gives rise to present and future benefits for workers, or is 'shared' or 'inclusive'. However, as shall be discussed in some of the cases in Section 4, most prominently in Kolkata jute textile industry, there may be a difference between the perspective of individual capital, or even a collective perspective of capital in a particular sector, and the perspective of capitalist development at a macro-level.

In contrast to the conventional conception of development, Selwyn (2014: 44) proposes 'labour-centred development', where 'labouring classes and their struggles against exploitation by capital are politically prioritized, and are conceptualized as "developmental" because they can deliver improvements to workers' (and their families' and communities') livelihoods'. In other words, labour's perspective on the function of LMIs as means to gain greater control over the labour process and to mobilise labour's interest is consistent with this 'labour-centred' conception of development. But once again in practice, labour mobilisation leading to gains for workers in a section of an economy does not necessarily immediately imply allencompassing mobilisation or improvements in conditions for the working class as a whole (Pattenden 2016). As Lebowitz (2003) suggests, labour's struggle for its own development can coincide with capitalist development, but this is process is not automatic and often uneven (Das 2012). Thus, if LMIs are to be evaluated for their developmental implications, it matters which benchmark for development is to be prioritised, and this issue will be revisited in the Conclusion of this paper.

\section{Fieldwork data and context}

The empirical analysis of labour-management relations in this paper is based on fieldwork in various regions of India in 2001 and 2013-14. This period coincided with a phase of rapid economic growth, with the GDP growth rates averaging 8.9 percent between 2003-04 and 2007-08, and manufacturing growth rates averaging ten percent during the same period. The impact of 2008 global financial crisis has led to a so far unstable economic growth pattern in India, with GDP growth rates fluctuating between 
4.5 and 8.9 percent over the past six years. The 2003-08 economic boom was driven by export growth particularly in the manufacturing, and the chemical and pharmaceutical sectors (Mohanty 2013; Nagaraj 2008; 2014), and accompanied moderate employment growth in the formal manufacturing sector averaging 7.5 percent per annum (Goldar 2011; Nagaraj 2011). It is worth noting that employment in the formal or 'organised' sector $^{4}$ in India has accounted for less than 10 percent of the total working population (Harriss-White 2003, 5). However, there has been intensification in the continued trend of 'nesting of the informal within the formal' with an increasing proportion of employment characterised by 'temporary contracts or casual arrangements and lacking social security provisions' (Samaddar 2009, 34).

More disaggregated analyses indicate that the past decade has also been a period of structural change in India's organised manufacturing employment, with employment shifting away from historically traditional industrial centres such as Mumbai (Bombay) in Maharashtra and Kolkata (Calcutta) in West Bengal. Instead, over recent decades employment growth has been observed in cities and towns adjoining larger metropolises, in rural areas, as well as in other newer industrial centres of India, such as: Gujarat, which neighbours Maharashtra; Tamil Nadu in south India; the National Capital Region (NCR) in north India; and further north in Himachal Pradesh and Uttarakhand; amongst others (Goldar 2011; Chandresekhar and Sharma 2014). This structural change in employment patterns can be seen as a consequence of shifts in industrial locations (Pandey and Shetty 2014), on the one hand, and the changing flows of labour migration patterns (Kundu and Saraswati 2012), on the other, which saw declines in concentration of factory and labour migration in-flows to cities such as Mumbai and Kolkata 5 .

The empirical analysis provided in this paper is intended to capture some important aspects of the regional and sectoral diversity in changes to LMIs in the context of

\footnotetext{
${ }^{4}$ In India, the organised sector is defined in terms of industrial sector classifications, the size of the establishment, and usage of power. See Miyamura (2010) for details.

${ }^{5}$ As suggested by Silver (2014) amongst others, the observed industrial restructuring is also part of broader processes of the relocation of manufacturing under global capitalism.
} 
industrial restructuring in India. For this purpose, two rounds of fieldwork, the first in 2001 and the second in 2013-14, have been carried out, with samples chosen from regional and sectoral 'strata' outlined in Table 1.

(Table 1)

As LMIs are conceptualised as regulating social relations of production, it is important that our analysis of their forms and functions take into account of differences in technological and organisational conditions. For this purpose, fieldwork has been carried out in a number of mills and factories in a wide variety of different types of industrial activities, which might be categorised as 'traditional' and 'modern' industries. Jute textile manufacturing in Kolkata and cotton textile manufacturing in Mumbai are represented by the 'traditional' sector, both industries with historical roots in the $1850 \mathrm{~s}$. Conventional mills in this sector are characterised by labour-intensive nature of production and relatively small changes in the technology used, although there are a small number of 'progressive' mills that have adopted newer labour-replacing technology in recent decades as discussed in Section 4.1. In contrast, the 'modern' sector includes a wider range of different types of manufacturing firms, which are relatively new, although some were established as early as the 1920s and '30s. The production technology in the 'modern' sector units is more capital-intensive, and many of the production processes require much higher levels of technology and skills than in jute and cotton textile manufacturing. Although none of these factories is operating at the global technological production frontier, the discussion in Section 4 shows diverse trajectory of technological changes in Indian industries. While some production units surveyed in this research saw technological upgrading and improvements in labour productivity, others such as the Kolkata jute textile sector have seen limited changes to production technology and organisation. Diversity and dynamics of institutional arrangements in regulating labour regulations will be interpreted in the context of this uneven development.

In addition to the differences in technological and organisational conditions, the capacity for different sections of capital, labour and the state to reshape the regulation over relations of production also depends on the historical context of industrial development and the particular ways in which labour management has been institutionalised within the broader political economy. The two main sites of the 
fieldwork have been Kolkata and Mumbai ${ }^{6}$, which were amongst the oldest industrial centres of India dating from the colonial period (Sinha 2006; Roy 2013), and also have been amongst the focal points of organised labour movement at least since the late 19th century. However, their industrial performances diverged from the late 1970s, with Mumbai associated with more rapid industrial development, while Kolkata has generally been characterised by relative stagnation (Baddeley et al. 2006; Miyamura 2010; Roy 2013). As discussed above, both cities have experienced industrial restructuring in recent decades, characterised by closure of factories and shifts of production to other regions where large-scale industrialisation and organised labour movements are historically less established, and the local state is less attentive in applying labour laws. These contextual specificities will be invoked in discussing the emerging patterns of LMIs in Section 4.

The above dynamics of industrial restructuring is reflected in the 13 year gap between the two fieldwork rounds, whereby many of the units surveyed in 2001 terminated and relocated production either to other cities or rural areas within the State, or to other parts of India. Deindustrialisation was particularly severe in Mumbai, reflected in only one out of 11 units surveyed in 2001 still operating in 2014. While attempts were made to resurvey units that remained open for production, for those that relocated the survey was conducted at the new unit where feasible. This meant that the fieldwork sites extended beyond the two cities from 2001, as mapped in Figure 1. They included various urban and rural areas within Maharashtra as well as the neighbouring State of Gujarat, and industrial areas in the Delhi-NCR (National Capital Region), Haryana and Himachal Pradesh. Several additional units ${ }^{7}$ were also surveyed in Kolkata and Mumbai in order to further deepen the understanding of the process of industrial restructuring and relocation. Overall, information from a total of 35 units was obtained.

\footnotetext{
${ }^{6}$ Strictly speaking the fieldwork extended to units located in neighbouring districts beyond the administrative boundary of both cities, such as Howrah in West Bengal and Navi-Mumbai in Maharashtra. However, for simplification we shall use Kolkata and Mumbai to refer to industrial sites in the greater metropolitan area in and around the two cities.

${ }^{7}$ In units that were studied during the 2014 fieldwork, but not in 2001, information on LMIs around 2001 was obtained through interviews with managers and union leaders, where possible.
} 
(Figure 1)

Sample selection from the four strata was non-probabilistic: access to factory units depended heavily on personal contacts and cooperation. The selection can be considered 'judgemental' or 'purposive' in that they were based on certain predetermined criteria, as outlined in the 'strata' in Table 1, ensuring that units with a variety of technological and performance-levels, and market status within the sector were included (see also Miyamura 2011). Given the lack of information on the relationship between the sample and the sampling frame, it is difficult to evaluate the extent of 'representativeness' of the data, but for the reasons discussed above, it is likely that the sample captures some aspects of the diversity and dynamics of labour-management relations in Indian industry. The empirical analysis of this paper combines descriptive statistics of the fieldwork data with case study approaches, which have allowed for significant empirical depth not achievable with available survey data. Although the objective of the case studies is to analyse institutional arrangements in labour-management relations in the sample, rather than to demonstrate its representativeness, comparison will be made with other studies as additional empirical support.

\section{Multivariate analysis of labour market institutions (LMIs) in Indian}

\section{industry}

The purpose of the remainder of this paper is to empirically examine the conceptual and theoretical issues outlined in Section 1. To describe the broad patterns in forms of LMIs, seven variables are selected. While not exhaustive, these variables are conventionally used in the literature to characterise institutional forms of labourmanagement relations as discussed in Section 1.2, and are relevant to the particular Indian context (for example: Freeman and Medoff 1984; Calmfors and Driffill 1988; Banerji, Campos, and Sabot 1995; Teitelbaum 2011; see Miyamura 2010 for further discussion). This includes unionisation, levels of bargaining, affiliation of unions to external organisations, types of union leaderships, bargaining parties, and ownership types of the firm. All seven variables measured by dichotomous variables, and their definitions and descriptive statistics are listed in Table 2.

(Table 2) 
(Table 3)

(Figure 2)

(Table 4) [EDITORIAL NOTE: Figure 2 and Table 4 to be on the same page]

As a statistical method, multidimensional scaling (MDS) is adopted to reduce the number of dimensions in the data matrix and categorise types of LMIs in the surveyed units. MDS is an explicitly data exploratory method that does not impose predetermined probabilistic models in its procedure, but instead used to examine broad patterns of similarities and differences in the forms of LMIs amongst units surveyed. The objective of the MDS is to 'map' these units in a reduced multidimensional space, so that their relative positions in the space reflect the rank order of proximities between these observations (see Dillon and Goldstein 1984).

Fifty observations (consisting of 35 units, of which for 15 units, data from both 2001 and 2013-14 fieldwork periods were used) are plotted along two dimensions in Figure 2, according to their configuration coordinates obtained from MDS. Observations from the two rounds of fieldwork are pooled together, and therefore the MDS process does not take into account the two periods. Note that the MDS is merely used to describe the broad patterns in forms of LMIs; it is recognised that the time dimension is significant in analysing changes of LMIs between the two fieldwork periods, and therefore will be an important focus in the interpretation of the MDS mapping when the dynamics of LMIs are examined in Section 4.

The MDS mapping is plotted along two dimensions that explain the highest proportion of the total variance (eigenvalues), and which sufficiently capture the general structure of the original data. The two dimensions thus retained from the MDS procedure are interpreted to characterise two aspects in types of LMIs dominant in the data: (1) the extent of centralised or state-mediation in LMIs and (2) the reduction in the extent of externalisation of LMIs and unionism. The interpretation of these two dimensions is justified on the basis of table 3. Dimension 1 is most strongly correlated with CENTRAL, a variable denoting centralised collective bargaining; followed by TRIPARTITE, which indicates that bargaining is tri-partite involving the state. Dimension 2 has strong negative correlations with: PLANT, suggesting presence of localised unit-level bargaining; UNION, which represents unionisation; and INTERNAL, 
a variable designated for union leadership from within the rank-and-file of the workplace. That these two dimensions are found to be the more dominant features of the LMIs in India is consistent with the literature (see for example, Rudolph and Rudolph 1987; Ramaswamy 1988; Bhattacherjee 1999). Note that the figures along the two dimensions merely represent the final iterative solution in the MDS procedure and do not have an absolute meaning. Our interest in the MDS mapping in Figure 2 is that the derived spatial distances between points in the mapping corresponds to the 'proximities' of values in the original seven variables, and thus allows interpretation of broad clustering of institutional forms observed in the surveyed units.

The MDS procedure resulted in 11 'points' plotted on the mapping, labelled alphabetically from A to $\mathrm{K}$, representing different combinations of institutional forms measured by the seven variables. Most of these points in the MDS mapping contain multiple surveyed units, reflecting that they share the same combination in values of the seven variables used in MDS, and in this sense can be interpreted as 'types' of LMIs categorised in terms of particular formal characteristics. Many of these points also broadly correspond to the 'strata' in the survey design of the fieldwork as summarised in table 1.

Clustering of units in each stratum that are interpreted to represent the typical LMIs in the region and sector are circled by dotted lines, and discussed in the following subsections. The clusters of LMIs types identified ${ }^{8}$ are for Kolkata traditional; Mumbai traditional; Kolkata modern; and Maharashtra/ Gujarat/ NCR modern.

Forms of LMIs as mapped out in Figure 2 can be useful in highlighting interesting findings and raising valuable questions. First, it shows that these broad forms of LMIs

\footnotetext{
${ }^{8}$ Point $\mathrm{E}$ is included in the cluster of Kolkata modern sector, but with a finer dotted line: this represents a public sector jute textile machinery factory that has a different institutional form from the other units in the Kolkata modern sector, and instead is closer to those in the Kolkata traditional sector. Point F corresponds to a private cotton textile mill in Mumbai with a LMIs type deviating from that conventionally established in the Mumbai traditional sector, and thus is not included in a cluster. Point $\mathrm{K}$ is also not circled into any of the cluster: this embodies all units without trade union representation in the factory and thus is not specific to any region or sector.
} 
are primarily characterised by the two dimensions: the degree of centralisation in labour-management relations and the extent of internalisation of bargaining agents. This finding is in line with existing studies, such as Calmfors and Driffill (1988) and Aidt and Tzannatos (2002), and is also consistent with much of the focus of policy debates in India (for example, see GoI 2002). Second, far from the stereotyping of organised and unionised labour into a single 'Indian model', the diagram also confirms the diversity in forms of LMIs in Indian industry. Third, although with some overlaps and exceptions, many of the clusters identified seems to correspond to the regional and sectoral clusters in the research design outlined in table 1. Fourth, on the basis of the seven variables used to characterise forms of LMIs, institutional forms changed dramatically in some units, whereas they remained relatively resilient in others. Although this final observation is not visible in Figure 2 due to pooling of data, it is discussed in Section 4 below.

\section{Diversity and dynamics of LMIs in Indian industry}

As discussed in Section 3, form-centred analysis formulated in the MDS mapping in Figure 2 allows confirmation that there is broad correspondence between forms of LMIs and regional/ sectoral groupings. The challenge for institutional analysis is to explain the observed diversity in forms of LMIs, examine how they function, and account for their changes. In the course of the discussion, references will be made to individual units. To comply with the confidentiality agreements with interviewees, units are identified by codes, consisting of the strata and an identity number: KT denotes 'Kolkata traditional'; KM signifies 'Kolkata modern'; MT is 'Mumbai/ Maharashtra traditional'; MM represents 'Mumbai/ Maharashtra modern'; GT stands for 'Gujarat traditional'; GM corresponds to 'Gujarat modern'; and NM is for 'NCR/ north India modern'.

From the viewpoint of the credibility thesis, of particular interest are cases where institutional changes were observed, and to examine the extent to which these were associated with rising contestation over prevailing LMIs. Amongst the 35 surveyed units, 11 units are identified to have had formal changes to their LMIs. Of these, four cases are identified to have had changes to their institutional forms at the same unit between 2001 and 2013-14, whereas all other cases involved relocation of production. 
Table 5 summarises the changes to institutional forms and their trajectories in surveyed units.

(Table 5)

\subsection{Diverging trajectory of LMIs in 'traditional sector' units in Kolkata and Mumbai}

Conventional forms of LMIs in 'traditional' sector units are represented in points A-D, clustered in close proximity, and differentiated from the LMIs in 'modern' sector units on MDS mapping in Figure 2 principally by labour-management bargaining being held at the industry-level. They are also characterised by the presence of party-affiliated unions, external leaders, and explicit state involvement in tri-partite collective settlements. The more centralised collective bargaining in the 'traditional' sector can be, at least in part, explained by the more standardised and labour-intensive but less skilldemanding production technology, in that wages and job classifications for equivalent tasks are easier to be harmonised across the sector. That this settlement is mediated by the state and political parties implies an acceptance of LMIs by labour, capital and the state in proving stable conditions for production to continue in return of securing minimum standard of wages and protecting employment and other fringe benefits.

Kolkata jute textile represents a sector where fragmented party-affiliated unionism and state moderated industrial relations have so far been the most resilient amongst the cases researched (see also Sen 1992). There has been no change in the number of mills and very little advancement of technology used over the past 15 years since the initial research (Miyamura forthcoming). All surveyed mills are covered by the industry-wide settlement negotiated by the employer association and up to 18 trade union organisations, divided along political party and factional lines. This feature has not changed since at least the 1970 s, although some mills have introduced separate milllevel settlements over the past 20 years. Part of reasons for the relative stability of LMIs in Kolkata jute textile industry can be sought in the context of the sector. Since the partition of Bengal in 1947, these mills have been under competitive pressure, first from Bangladesh's jute manufacturing sector, and later from polythene alternatives. This has been countered with a central government act that compels the Indian government to 
procure raw jute, distribute these to mills and use jute bags produced in the public distribution of agricultural goods, at fixed prices at both ends.

In contrast, all cotton textile mills surveyed in 2001, apart from one, have closed down in Mumbai by 2014. The one remaining in our sample (MT1) is amongst the three still in effective operation in the city, whereas there were 54 cotton textile mills in 1996. The cotton textile industry has faced competition from the handloom and powerloom sectors, as well as from imported goods since the 1970s. However, in contrast to the Kolkata jute, this led to an uneven technological adoption with a small number of private 'progressive' mills investing in new machinery and diversifying products for the domestic middle class market and exports, increasing gaps in productivity and profitability with the rest of the so-called 'backward' mills with obsolete technology (Bhattacherjee 1989). On the labour side, since independence textile mill workers were represented by Rashtriya Mill Mazdoor Sangh (RMMS), a union affiliated to the Congress party, which has been dominating the State of Maharashtra, where Mumbai is located. However, the increasing dissatisfaction with the party-affiliated union and the state-mediated industry-level collective settlements led to workers bring in a non-partyaffiliated union in an attempt to oust the RMMS, and triggered the Bombay textile strike of 1982-83. On the capital side, the uneven development led to a widening of division amongst mill owners in the employers' association, eventually leading to the collapse of the prevailing LMIs and eventual discontinuation of the industry-wide pay negotiations after 1992 (Kulkarni 1999).

MT4 and MT5 represent two privately-owned cotton textile mills in Mumbai, which broke away from the industry-wide collective bargaining, and conventional forms of LMIs associated with the cluster A-D in Figure 2, in the mid-1980s. The departure from the industry-wide bargaining and localisation of the labour-management relations are reflected in the shift of their forms of LMIs to the left in the MDS mapping, but differentiated by the affiliation (F) or otherwise (I) to political party of the unions representing their workers. MT4 represents one of the 'backward' mills, where the owner gradually diversified mill lands for profitable real estate investments, given the location in the commercial centre of the city. Although the RMMS continued to act as the sole recognised union by the mill owner, workers at this mill were represented by a civil society organisation-like union, the Girni Kamgar Sangharsh Samiti (GKSS), which was formed in 1996 to struggle for rehabilitation of workers who lost their 
livelihood as a result of closures. While both mills eventually closed down in Mumbai, the more profitable 'progressive' textile unit, MT5, had its production shifted to new composite mills located near Vadodara in Gujarat, GT1, currently operating using the 'state-of-the-art' technology and with non-unionised workers, as indicated by the upward shift to non-unionised LMIs type K.

The comparison of the two sectors implies the potential role played by technology in institutional change. Whereas the prevailing LMIs have persisted in Kolkata jute textile mills where technological change has been limited, the uneven introduction of new technology in the Mumbai cotton textile industry saw institutional change and eventual collapse. But it could also be argued that the technological change was a reflection of both capital and labour's contestation over and the loss of 'credibility' of the LMIs. Significantly, the trajectory of institutional change has been diverse despite all these units having similar LMIs two decades ago, represented in the cluster A-D in Figure 2. This supports the credibility thesis' caution against presuming a theoretically predetermined form-function relations, and also the postulation that the institutional credibility is associated with the level of conflict (Ho 2014: 23).

Evaluating functions of LMIs reveals potentially conflicting perspectives. The stability in the form of LMIs in Kolkata jute may imply those representing the interests of labour, capital and the state in the sector have so far been accepting the prevailing institutional arrangements, but the outcome may not be 'developmental' either from labour's or capital's viewpoint. Indeed, technology and product diversification that can potentially overcome the stagnating condition of the jute textile sector are available, and there are indications that certain sections of labour, capital and the state recognise the need for institutional change (Miyamura forthcoming). Similarly, although the industrial conflict and the eventual breakdown of LMIs were associated with some flourishing of alternative forms of labour organisations, it also led to the loss of employment and livelihood for a large section of mill workers in the Mumbai textile industry. From capital's perspective, a small number of mills have upgraded their technology and increased labour productivity, although this accompanied increased casualisation of the labour force, the majority of whom have no access to institutionalised forms of dispute resolutions. The rest of the cotton textile mills in Mumbai have closed down, with their production shifting to the informal sector. Mill lands have been diverted to real estate investments, which may have profited the individual owners but once again raises 
question as to whether the result has been 'developmental', certainly from labour's or society's viewpoints, but also from the perspective of the capitalist class as a whole.

\subsection{Comparison of LMIs in the modern sector in Kolkata and Mumbai}

Despite the heterogeneity of products and business activities amongst units included in the 'modern' sector category, all but one unit ${ }^{9}$ based in Kolkata are represented by points $\mathrm{G}$ and $\mathrm{H}$, clustered in close proximity around the bottom of the mapping in Figure 2, reflecting similarity in institutional forms as measured by the seven variables used for the MDS. As shown in Table 4, all units mentioned above are characterised by plant-level bargaining; presence of party-politically affiliated unions, but organised and led internally at the unit; and being in the private sector. The two points are differentiated by whether the bargaining involves the state as an explicit mediator $(\mathrm{G})$ or $\operatorname{not}(\mathrm{H})$.

The decentralised form of collective bargaining common to all these 'modern' sector units can be understood as reflecting the greater variation in economic conditions, which makes levelling of compensation structure and working conditions by centralised industry-level settlements typical in the conventional institutional forms of the 'traditional' sector (A-D) difficult to sustain. Interestingly, all Kolkata 'modern' units represented by points $\mathrm{G}$ and $\mathrm{H}$ had party-political trade unions representing workers. Kolkata has seen a dominance of party-affiliated unions, especially the Centre of Trade Unions (CITU) affiliated to the Communist Party of India (Marxist), or CPI(M), which was in power in its State of West Bengal between 1977 and 2011. However, the partypolitical form of unionism should not be associated with the ideological position of the party, which in any case have moved away from the initial stance of revolutionary communism soon after taking power (Ramaswamy 1988; Kohli 1990). When the CPI(M) was replaced by the All India Trinamool Congress (TMC), it too has subsequently attempted to reproduce a similar party-union nexus since 2011 (see Miyamura forthcoming). That the party-political form of LMIs continue to dominate in these units, despite TMC's frequent criticism of CPI(M)'s style of trade union politics, indicate structural roots in the party political forms of LMIs in Kolkata.

\footnotetext{
${ }^{9}$ KM6 in 2001, prior to privatisation; see below.
} 
Compared to the more closely clustered G-H, representing types of LMIs of 'modern' sector unionised private firms in Kolkata, LMIs of corresponding firms in Mumbai appear to show greater diversity in their institutional forms. In the MDS mapping presented in Figure 2, unionised 'modern' sector units based in Mumbai/ Maharashtra are represented by three types of LMIs: H, I and J, all of which are privately-owned companies characterised by bi-partite, plant-level bargaining, as summarised in Table 4. The distinctions lie in the type of unions and union leadership. Type H, which also included a number of Kolkata-based units, is characterised by party-political unions but with internal leaders. In contrast, units categorised as type I have so-called 'independent' unions that are not affiliated to political parties, but have union leadership linked to external organisations; whereas in type $\mathrm{J}$ units the unions are run by internal leaders free from any external links.

In addition to their diversity, what also distinguishes forms of LMIs in these units from their counterparts in Kolkata is the relative fluidity in which institutional forms appear to have changed between and within different LMIs types. For example, MM4, a pharmaceutical plant located in Mumbai, had union-affiliation shifting from the Socialist Party (point F); a non-party political external leader (point I); and to the Trade Union Centre of India (TUCI) under the influence of the 'ultra-left' Communist Party of India (Marxist-Leninist) (point $\mathrm{H}$ ).

The more diverse and fluid institutional forms in Mumbai's 'modern' sector compared to its Kolkata counterparts is difficult to explain on the basis of technology alone, given that the 'modern sector' in both cities includes a mix of comparable production units. While the stability of prevailing LMIs in Kolkata jute textile aforementioned in Section 4.1 may partly be attributed to regulations, none of the units in the modern sector discussed here receives similar level of government protection. That party-affiliated unionism dominates and continues to be relatively stable in Kolkata despite decentralised bargaining structure once again implies the continued relative importance of organised labour for political mobilisation in West Bengal. In contrast, Maharashtra, where Mumbai is located, is one of regions in which the Congress party has dominated the State politics, apart from being ousted from power in 1995-99, and recently in October 2014. Like the CPI(M) in Kolkata, the Congress has also attempted to incorporate organised labour through its trade union wing, and in sectors such as textile, has imposed it as the sole representative union, as discussed in Section 4.1. However in 
Maharashtra, the importance of organised labour in regional politics diminished and while party-affiliated unions continue to exist, Mumbai became the centre of the socalled new trade union movement since the 1960s with independent unionists increasingly gaining influence (Bhattacherjee 1998; Hensman 2011). The dynamics of LMIs, especially in relation to the type of union leadership and their affiliation, appears to reflect the capacity of rank-and-file workers to contest prevailing institutions, although this is not simply by party-affiliated unions being replaced by independent or internal leaders in Mumbai. While in some cases party-affiliation was abandoned in favour of independent or internal leaders, in others Mumbai workers have strengthened external ties and in some cases even ousted internal leaders. To examine this, further trajectories of changes to institutional forms are discussed next.

\subsection{Dynamics of LMIs}

This sub-section draws on selected cases of institutional change to discuss factors underlying their trajectories. Significantly apart from one case, changes in forms of LMIs involved exacerbation of labour-management conflict. The only exception to this is KM6, a Kolkata-based engineering plant manufacturing jute textile machinery, which, at the time of study during the 2001 fieldwork was in public hands, with the West Bengal State Labour Minister and the Chief Minister mediating in labourmanagement settlements. Privatisation of this unit is reflected in the shift of KM6 from points $\mathrm{E}$ to $\mathrm{G}$ in Figure 2, although the state still retains an 'advisory' role in collective bargaining.

Of the observed cases of institutional change, KM10, a plant manufacturing water dispenser originally in Kolkata, and two units, NM1 and NM2, located in the industrial area in the national capital region (NCR) around Delhi and belonging to separate passenger transport vehicle companies both with foreign direct investment, have seen formation of trade unions between the fieldwork periods. This is reflected in KM10 and NM1 shifting from $\mathrm{K}$ to $\mathrm{H}$, and NM2 to $\mathrm{J}$, the difference being that the union is affiliated to a labour-wing of a political party in the former two units, while the latter is unaffiliated to any external organisation. These cases run against the popular perception of diminished roles of trade unionism under neoliberal globalisation, and also are of importance in the context of India's on-going policy debate. 
Apart from these four cases, there are also several cases where formal changes to LMIs, as measure by the seven variables used in MDS, had taken place prior to the initial fieldwork of 2001, including at MT4, MT5 and (the aforementioned) MM4. There are also certain changes to institutional forms that were not captured by the variables adopted: for example, many units in Mumbai had seen trade unions shifting their affiliation from one political party to another. However, the majority of formal changes to LMIs in surveyed units accompanied closure of units and relocation of production.

The abovementioned union formation in KM10, the water dispenser manufacturing plant, resulted from concerns amongst workers that the management was planning to shift its production away from Kolkata, affiliating themselves to CITU in order to gain support from CPI(M), which was still in power. Two years after unionisation, and a CPI(M) brokered voluntary retirement scheme (VRS) and retrenchment settlement, the company shifted production to NM4, located in the north Indian region of Chandigarh and operates without a union, reflected in a shift to point $\mathrm{K}$.

While in the above cases production shift accompanied de-unionisation, this was not always the case. KM5 and MM3 were light bulb and lamp factories with more or less the same production technology and organisation, and managed by the same multinational company, but were operating in Kolkata and Mumbai respectively. While KM5 had a CITU-affiliated union (represented by point G), MM3 had a plant-based union (point J), both of which were linked under the umbrella of a India-wide company federation of unions set up in 1971, but which eventually collapsed in 1986. The company closed both units in the mid-2000s, shifting their production to GM1 near Vadodara in Gujarat, initially operating without unions (K). Several attempts to organise workers at the new site GM1 resulted in activists being retrenched, with the management instigating a 'workers' committee', which activists allege was 'psudomanagement'. In 2012, the management recognised setting up of an independent plantbased union $(\mathrm{J})$, but based on members of the workers' committee, prompting some criticism as a 'management's union', although the union leaders are keen to disassociate themselves from this image.

In other cases where unionisation was maintained in the relocated unit, capacity to build solidarity and linkages with extra-plant organisations and movements was significant. MM6, a Mumbai-based assembly plant run by an Indian automobile company was 
closed in the early 2000s, with its production shifted to MM10, near Pune, Maharashtra. MM6 had two unions, both party-unaffiliated (categorised as point I), which followed the company to MM10. An industrial dispute unfolded when another Pune-based external union joined and the management attempted to eject unions from the previous plant. In 2010, the three unions merged to form an internal union led by rank-and-file workers, with the support of an independent federation of unions in the region, thus shifting LMIs to point $\mathrm{J}$.

Similarly, MM5, a Mumbai plant belonging to a multinational consumer goods company closed down in 2004, with its soap manufacturing shifting to MM8, located in Khamgaon in north east Maharashtra, and the detergent production shifting to MM9 in a central-government controlled Union Territory of Dadra and Nagar Haveli, bordering Maharashtra and Gujarat. Before the closure, workers at the old Mumbai plant MM5 was represented by a union, which also continues to act as a headquarter of a federation to build solidarity and resources for unions under the company. Both of the new sites, MM8 and MM9, have internal unions with links to the company's union federation, although with difference in party-political affiliation.

The above comparisons of LMIs and their changes illustrate that institutional change occurred in the context of conflictual industrial relations in which capital and labour (sometimes with state involvement) contested the prevailing institutional arrangements for workplace regulation. Once again, this supports the thesis of associating institutional credibility with contestations.

The trajectories and outcomes of these changes appear also to be associated with the different capacity of workers to mobilise collective action of their own, whether to defend their livelihoods or to build solidarity beyond their narrow economic interests. For example, unionisation in the multinational transport vehicle companies in the NCR, NM1 and NM2, was achieved through workers' mobilisation over several years, facing attempts by the management and the State government to undermine their formation, and involving a number of high profile confrontations that resulted in violence. Unions at these multinational transport vehicle companies appear to at least attempt to mobilise struggles on issues beyond the narrow interests of their members, for example, by supporting strike action by contract workers demanding wage equalisation to permanent workers, or taking solidarity action with unions in disputes at other factories in the 
region. Similarly, workers at the automobile plant in Pune, MM10, were able to consolidate its labour organisation with the support of regional union federation.

In this context, a comparison of two cases of India-wide company federation is particularly of interest. The management strategy to undermine extra-factory union federations, combined with closures of their organising hubs, resulted in the collapse of the federation and narrowing of union strategies to unit-level gains in the light bulb and lamp factories (MM3/ KM5/ GM1), whereas in the soap and detergent company (MM5/ MM8/ MM9), the federation has not only been retained, but strengthened even after the relocation of production. The latter company union federation in the multinational soap and detergent company cultivated access to international organisations and diplomatic communities, and linked its struggle to global solidarity movements as means to strengthen their capacity to contest LMIs. However, far from a transition from a 'national period' to a 'new period of labour internationalism' (Munck 2002: 154), the capacity of these unions to appeal to international organisations and movements was based on their 'associational power' (Wright 2000: 962) at the plant level. It also once again supports the credibility thesis in their rejection of form-function relation, in that apparently similar institutional form has been observed to result in very different trajectories of institutional change.

\section{Conclusion}

The findings of this paper shows the scope of the credibility thesis in moving debates on LMIs beyond the fixation on form-function relations, and opens the possibility for institutional change to be interpreted as reflecting the intensification of conflict and contestation over prevailing institutional arrangements. Given the antagonistic nature of social relations of production, the stability of institutional forms may not necessarily signal lack of conflicts in labour relations. But the observation that formal institutional change accompanied heightening of industrial conflicts in all but one production units in this study is consistent with the link between institutional credibility and conflict postulated.

In addition to conflict over LMIs, the majority of cases in which changes to the form of LMIs were observed experienced relocation of production from traditional industrial centres to sites with limited history of industrial labour movements. From the 
perspective that forms of LMIs are tied up with other political and juridical institutions, it is perhaps not surprising that shifting production to a location with a very different social structure triggers changes to institutional forms. Moreover, it is significant that, while relocation was associated with de-unionisation in some cases (MT5/GT1 and KM10/NM4), in others unionisation was maintained (MM6/MM10 and MM5/MM8/MM9) or reorganised (KM5/MM3/GM1). In the latter case, even in the period without unions, the plant had a 'workers' committee' to mediate labourmanagement relations. These observations highlight the continued importance of LMIs even in regions where workforce has historically not been unionised. This is significant in the context of policy propositions in favour of non-unionised 'flexible' labour regimes in India.

The observation that LMIs have been less diverse and more stable in Kolkata than in Mumbai goes against presumption made in some theoretical models (Banerji, Campos and Sabot 1995; Pencavel 1995) as well as policy propositions in India (GoI 2002), which associate party-political forms of LMIs with labour militancy and unstable industrial relations. Indeed, Kolkata has generally been associated with declining industrial disputes in general, and strikes in particular (Shyam Sundar 2004). It is possible that party-affiliated unions strengthens the ability of the state to mediate and 'restrain' labour militancy (Teitelbaum 2011). For the credibility thesis, the observation once again renders theoretical postulation of form-function relations redundant, and confirms the importance of socio-historical contexts. For example, the process involved in workers at MM4 seeking affiliation to political parties in their attempts to strengthen the bargaining power of their unions and to direct unions to focus their negotiations on particular issues of concern, is very different to that in the Kolkata jute textile industry, where the dominance of party-affiliated unions has limited alternative forms of LMIs to emerge. Also, that political regime change from CPI(M) to TMC in 2011 resulted in reinforcement of party-union nexus in Kolkata, despite their difference in ideological orientations, can be taken as further caution against form-function links presumed by political ideology or conviction. One of the implications of these findings is that ongoing policy debates on labour market reforms in India focusing on exogenous policy engineering of LMIs may be misplaced. Engineering institutional changes exogenously based on predetermined ideological convictions may not necessarily result in LMIs 
performing in the desired manner to bring about industrial 'harmony' or to deliver improvements in livelihoods.

The findings of this paper also reveal that functions of LMIs can depend on whose perspective they are to be evaluated. On the one hand, the resilience of LMIs may imply stable conditions for production to continue and employment to be maintained for incumbent managers and workers in the formal sector establishments in Kolkata, but may not necessarily be 'developmental', either in the sense of dynamic capitalist development or labouring class struggles (Lerche 2010; Selwyn 2014; Pattenden 2016). On the other hand, the diverse and fluid LMIs in Mumbai may have reflected the capacity of both capital and labour to contest prevailing institutional arrangements, although this has eventually accompanied de-industrialisation and significant loss of employment in the city. Industrial relocation has in some cases led to 'development' either in technological upgrading and strengthening of labouring class mobilisation beyond the shop floor level, but in diverse and uneven ways, which once gain points to the importance of historically- and socially-sensitive analysis. These are question that conventional analysis focusing on institutional forms does not ask. The credibility thesis extended to LMIs in this paper offers a first step to addressing these issues.

\section{References:}

Agarwala, Ramgopal. 1983. Price Distortions and Growth in Developing Countries. World Bank Staff Working Papers, 575. Washington D.C.: World Bank.

Anant, T.C.A. (2009), "Revisiting Labour Market Regulation", Indian Journal of Labour Economics, Vol. 52, No. 2, pp. 195-202.

Baddeley, M., K. McNay and R. Cassen. 2006. Divergence in India: Income Differentials at the State Level, 1970-97. Journal of Development Studies 42:6: 1000-1922.

Banerji, Arup, J. Edgardo Campos, and Richard H. Sabot. 1995. The Political Economy of Formal Sector Pay and Employment in Developing Countries. World Bank Policy Research Working Paper No. 1435. Washington D.C.: World Bank.

Bensaïd, Daniel. 2002. Marx for Our Times: Adventures and Misadventures of a Critique. London: Verso.

Besley, Timothy and Robin Burgess. 2004. Can Labor Regulation Hinder Economic Performance? Evidence from India. The Quarterly Journal of Economics, 119:1: 91134.

Bharatiya Janata Party (2014), Election Manifesto 2014, http://bjpelectionmanifesto.com/, accessed 8 April 2014. 
Bhattacherjee, Debashish 1989. Evolution of Unionism and Labour Market Structure: Case of Bombay Textile Mills, 1947-1985. Economic and Political Weekly. 24:21, M67-M76.

Bhattacherjee, Debashish 1999. Organized Labour and Economic Liberalization: India: Past, Present, and Future. Labour and Society Programme Working Paper No. DP/105/1999. Geneva: The International Institute for Labour Studies, International Labour Organisation (ILO).

Bhowmik, Sharit K. 2006. Cooperatives and the Emancipation of the Marginalized: Case Studies from Two Cities in India. in Boaventura de Sousa Santos (ed.) Another Production is Possible: Beyond the Capitalist Canon. London: Verso.

Calmfors, Lars and John Driffill. 1988. Bargaining Structure, Corporatism and Macroeconomic Performance. Economic Policy, 3(6): 14-61.

Chandresekhar, S. and Ajay Sharma. 2014. On the Spatial Concentration of Employment in India. Economic and Political Weekly. 49(21): 16-18.

Chang, Ha-Joon. 2007. Institutional Change and Economic Development: An Introduction. In Institutional Change and Economic Development. ed. Ha-Joon Chang. Tokyo, New York, Paris: United Nations University Press/ Anthem Press.

Croix, G. E. M. De Ste. 1981. The Class Struggle in the Ancient Greek World: From the Archaic Age to the Arab Conquests. Ithaca: Cornell University Press.

Das, Raju J. 2012 'Reconceptualizing Capitalism Forms of Subsumption of Labor, Class Struggle, and Uneven Development.' Review of Radical Political Economics. 44:2, 178-200.

Deakin, Simon and Antara Haldar. 2015. 'How Should India Reform Its Labour Laws?' Economic and Political Weekly, 50:12, 48-55.

Dillon, William R. and Goldstein, Matthew. 1984. Multivariate Analysis. New York: John Wiley \& Sons.

Fallon, Peter R. and Robert E. B. Lucas. 1991. The Impact of Changes in Job Security Regulations in India and Zimbabwe. The World Bank Economic Review 5(3): 395413.

Freeman, Richard B. 1993. Labor Market Institutions and Policies: Help or Hindrance to Economic Development? . Proceedings of the World Bank Annual Conference on Development Economics 1992.

Freeman, R. B. and J. L. Medoff. 1984. What Do Unions Do? New York: Basic Books.

Goldar, Bishwanath 2011. Growth in Organised Manufacturing Employment in Recent Years. Economic and Political Weekly 46(7): 20-23.

Gordon, David M., Richard Edwards, and Michael Reich. 1982. Segmented Work, Divided Workers: The Historical Transformation of Labor in the United States. Cambridge University Press.Government of India (GOI) 2002. The Second National Commission on Labour Report. New Delhi: Union Ministry of Labour.

Grabel, I. 2000. The Political Economy of 'Policy Credibility': The New-Classical Macroeconomics and the Remaking of Emerging Economies. Cambridge Journal of Economics 24 (1): 1-19.

Harriss-White, Barbara. 2003. India Working: Essays on Society and Economy. Cambridge: Cambridge University Press.

Hensman, Rohini. 2011. Workers, Unions and Global Capitalism: Lessons from India. New Delhi: Tulika Books.

Ho, Peter. 2014. The 'credibility Thesis' and Its Application to Property Rights: (In)Secure Land Tenure, Conflict and Social Welfare in China. Land Use Policy 40: $13-27$. 
Kohli, Atul. 1990. From Elite Activism to Democratic Consolidation: The Rise of Reform Communism in West Bengal. In Dominance and State Power in Modern India: Decline of a Social Order. eds. Francine R. Frankel and M. S. A. Rao. Delhi: Oxford Univserity Press.

Kulkarni, Suchita. 1999. Impact of Restructuring of the Bombay Textile Industry on Labour and Labour Institutions. Indian Journal of Labour Economics. 42:4, 865-871.

Kundu, Amitabh and Lopamudra Ray Saraswati. 2012. Migration and Exclusionary Urbanisation in India. Economic and Political Weekly, 47(26-27): 219-227.

Lebowitz, Michael A. 2003. Beyond Capital: Marx's Political Economy of the Working Class. Basingstoke: Palgrave Macmillan.

Lerche, Jens. 2010. From 'Rural Labour' to 'Classes of Labour': Class Fragmentation, Caste and Class Struggle at the Bottom of the Indian Labour Hierarchy. In The Comparative Political Economy of Development: Africa and South Asia. eds. Barbara Harriss-White and Judith Heyer. London: Routledge.

Lerche, Jens. 2015. Making India? The Labour Law Reforms of Narendra Modi's Government. Paper presented at SSAI Panel Discussion: 'Assessing Modi's Track Record Eighteen Months On'. London: SOAS South Asia Institute.

Mangel, J. H., C. D. Jr. DeLorme, and D. R. Kamerschen. 1994. Rent Seeking and the Byproduct Theory of Labor Movements. Rivista Internazionale Di Scienze Economiche e Commerciali, 41(5): 399-422.

Marx, Karl. 1973. Grundrisse: Foundations of the Critique of Political Economy. London: Penguin.

Miyamura, Satoshi. 2010. Labour Market Institutions in Indian Industry: A Comparison of Mumbai and Kolkata. PhD thesis, London: School of Oriental and African Studies, University of London.

Miyamura, Satoshi. 2011. Diversity of Labour Market Institutions in Indian Industry: A Comparison of Mumbai and Kolkata. The Indian Journal of Labour Economics, 54 (1): 113-130.

Miyamura, Satoshi. 2012. Emerging Consensus on Labour Market Institutions and Implications for Developing Countries: From the Debates in India. Forum for Social Economics 41(1): 97-123.

Miyamura, Satoshi. 2016 forthcoming. Industrial Restructuring, Organisations of Labour and Patterns of Accumulation in India. Third World Quarterly.

Mohanty, Mritiunjoy. 2013. India: Globalisation and Growth. World Economic Review (URL: http://werdiscussion.worldeconomicsassociation.org/?post=india-globalisationand-growth, accessed 8 November 2013).

Munck, Ronaldo. 2002. Globalization and Labour: The New 'Great Transformation'. London and New York: Zed Books.

Nagaraj, R. 2008. India's Recent Economic Growth: A Closer Look. Economic and Political Weekly 43(15): 55-61.

Nagaraj, R. 2011. Growth in Organised Manufacturing Employment: A Comment. Economic and Political Weekly 46(12): 83-84.

Nagaraj, R. 2014. Economic Challenges to the New Government: A Policy Proposal. Economic and Political Weekly 49(21): 35-41.

Nickell, S. and L. Nunziata. 2001. Labour Market Institutions Database, Version 2, (www://cep.lse.ac.uk/pubs/download/data0502.zip, accessed 30 May 2006).

Nunziata, Luca. 2003. Unemployment, Labour Market Institutions and Shocks. presentation given at the New Directions in Labour Market Flexibility Research, London, Wednesday 26 November 2003 (http://www.dti.gov.uk/er/emar/events.htm, accessed 30 May 2006). 
Pandey, Shruti J. and S. L. Shetty. 2014. ASI Results for 2011-12: A More Positive View of the Industrial Scene. Economic and Political Weekly 49(21): 89-93.

Pattenden, Jonathan. 2016. Labour, State and Society in Rural India: A Class-relational Approach. Manchester: Manchester U.P.

Pencavel. 1995. The Role of Labor Unions in Fostering Economic Development. World Bank Policy Research Working Paper 1469. Washington D.C.: World Bank.

Ramaswamy, E.A. 1988. Worker Consciousness and Trade Union Response. New Delhi: Oxford University Press.

Roy, Pallavi. 2013. 'India's Vulnerable Maturity: Experiences of Maharashtra and West Bengal.' In: North, Douglass and Wallis, John and Webb, Steven and Weingast, Barry, (eds.), In the Shadow of Violence: The Problem of Development in Limited Access Societies. Cambridge: Cambridge University Press, pp. 198-232.

Rudolph, Lloyd I. and Rudolph, Susanne Hoeber. 1987. In Pursuit of Lakshmi: The Political Economy of the Indian State. London: University of Chicago Press.

Saint-Paul, G. 2000. The Political Economy of Labour Market Institutions. Oxford: Oxford University Press.

Samaddar, Ranabir. 2009. Primitive Accumulation and Some Aspects of Work and Life in India. Economic and Political Weekly. 44(18): 33-42.

Sen, Ratna. 1992. Jute Industry. In Employment and Unionisation in Indian Industry. ed. Sarath Davala. New Delhi: Friedrich-Ebert Foundation.

Sinha, Aseema. 2005. The Regional Roots of Developmental Politics in India: A Divided Leviathan. Bloomington, IN: Indiana University Press.

Silver, Beverly. 2014. 'Theorising the Working Class in Twenty-First-Century Global Capitalism.' In Maurizio Atzeni (ed.) Workers and Labour in a Globalised Capitalism: Contemporary Themes and Theoretical Issues. New York: Palgrave Macmillan.

Smith, C. (2006) 'The Double Indeterminancy of Labour Power: Labour Effort and Labour Mobility,' Work, Employment and Society, 20, pp. 389-402.

Standing, Guy. 1992. Do Unions Impede or Accelerate Structural Adjustment? Industrial versus Company Unions in an Industrialising Labour Market. Cambridge Journal of Economics 16: 327-354.

Teitelbaum, Emmanuel. 2011. Mobilizing Restraint: Democracy and Industrial Conflict in Post-Reform South Asia. Ithaca and London: Cornell University Press.

Thompson, Paul and Chris Smith (2009) 'Waving, Not Drowning: Explaining and Exploring the Resilience of Labour Process Theory,' Employee Responsibilities and Rights Journal, 21, pp. 253-262.

Wright, Erik Olin. 2000. Working-Class Power, Capitalist-Class Interests, and Class Compromise. American Journal of Sociology, 105:4, 957-1002. 
Table 1. 'Stratas' and the number of units surveyed

\begin{tabular}{|c|c|c|c|c|c|}
\hline & & \multicolumn{4}{|c|}{ Regions } \\
\hline & & Kolkata & $\begin{array}{c}\text { Mumbai/ } \\
\text { Maharashtra }\end{array}$ & Gujarat & $\begin{array}{c}\text { NCR/ north } \\
\text { India }\end{array}$ \\
\hline & Traditional & $\begin{array}{l}\text { Jute textile } \\
\text { manufacturing } \\
\left(\mathrm{n}_{01}=\mathrm{n}_{14}=4\right)\end{array}$ & $\begin{array}{l}\text { Cotton textile } \\
\text { manufacturing } \\
\left(\mathrm{n}_{01}=5 ; \mathrm{n}_{14}=1\right)\end{array}$ & $\begin{array}{l}\text { Cotton textile } \\
\text { manufacturing } \\
\qquad\left(\mathrm{n}_{14}=1\right)\end{array}$ & $\mathrm{n} / \mathrm{a}$ \\
\hline Sectors & Modern & $\begin{array}{c}\text { Light } \\
\text { engineering, } \\
\text { processing, } \\
\text { pharma etc. } \\
\left(\mathrm{n}_{01}=9 ; \mathrm{n}_{14}=4\right)\end{array}$ & $\begin{array}{l}\text { Light engineering, } \\
\text { processing, } \\
\text { pharma etc. } \\
\left(\mathrm{n}_{01}=10 ; \mathrm{n}_{14}=5\right)\end{array}$ & $\begin{array}{c}\text { Light } \\
\text { engineering } \\
\left(\mathrm{n}_{14}=1\right)\end{array}$ & $\begin{array}{c}\text { Light } \\
\text { engineering, etc } \\
\left(\mathrm{n}_{01}=2 ; \mathrm{n}_{14}=4\right)\end{array}$ \\
\hline
\end{tabular}

Note: $\mathrm{n}_{01}$ denotes the number of units for which data is available in 2001 ; while $\mathrm{n}_{14}$ is the number of units for which data is available from the 2013-14 fieldwork. The total number of observation used in the analysis of this paper is 50 (based on 35 units, of which for 15 units, data from both 2001 and 2013-14 fieldwork periods were used). 
Figure 1. Map of India and fieldwork locations

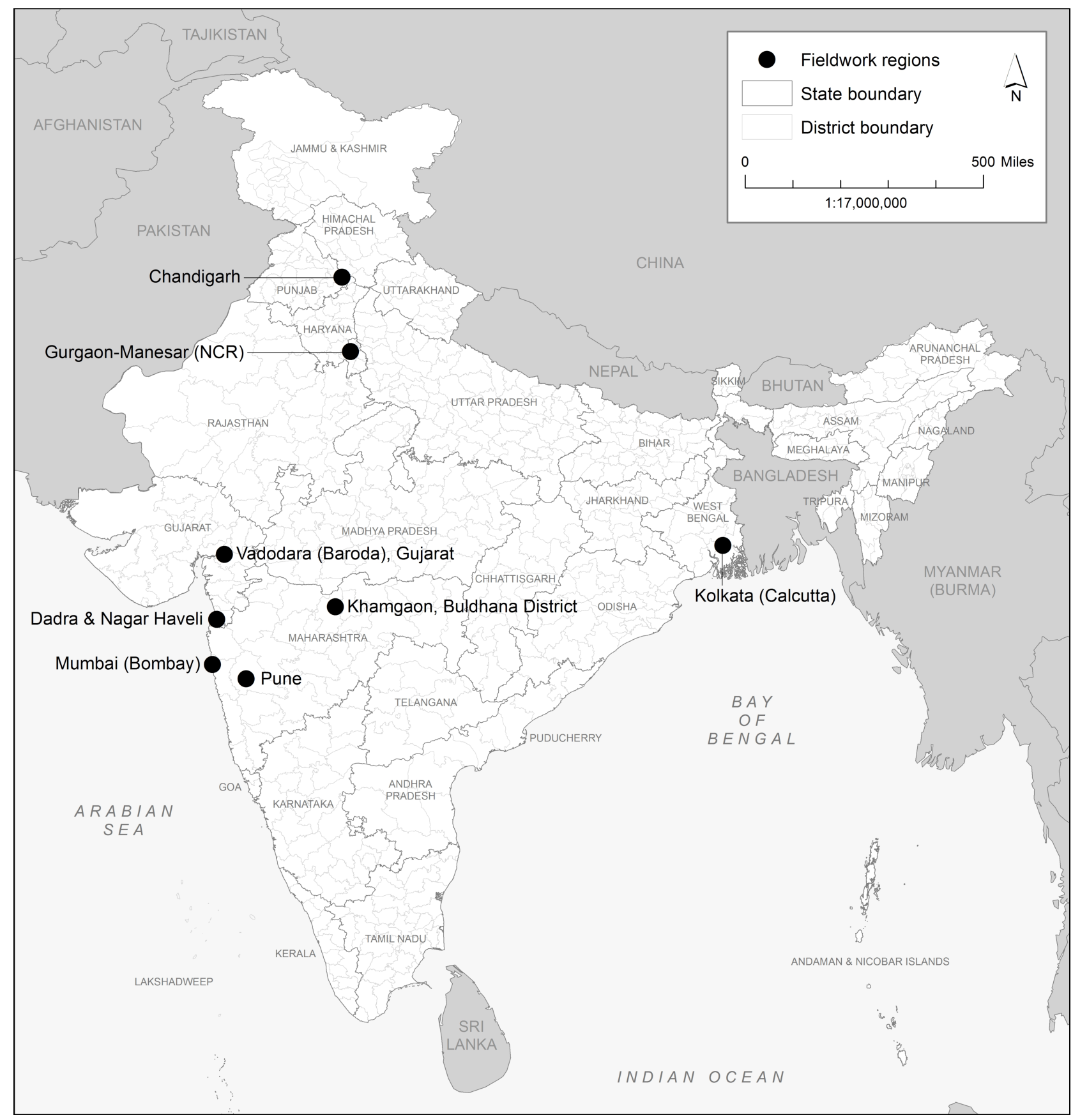


Table 2 Variables used for the multidimensional scaling (MDS) of LMIs

\begin{tabular}{|c|c|c|c|c|}
\hline Variable names & Definition & Sum & Mean & $\begin{array}{l}\text { Standard } \\
\text { deviation }\end{array}$ \\
\hline $\mathrm{UNION}^{(\mathrm{i})}$ & $\begin{array}{l}\text { Dummy variable on unionisation. } \\
1 \text { if unionised; } 0 \text { if otherwise. }\end{array}$ & $4 \overline{42}$ & 0.82 & 0.385 \\
\hline CENTRAL & $\begin{array}{l}\text { Dummy variable on the level of } \\
\text { collective bargaining. } 1 \text { if } \\
\text { centralised bargaining takes place; } \\
0 \text { if otherwise. }\end{array}$ & 13 & 0.26 & 0.443 \\
\hline PLANT & $\begin{array}{l}\text { Dummy variable on the level of } \\
\text { collective bargaining. } 1 \text { if } \\
\text { bargaining takes place at plant- } \\
\text { level; } 0 \text { if otherwise. }\end{array}$ & 36 & 0.72 & 0.454 \\
\hline POLITICAL (ii) & $\begin{array}{l}\text { Dummy variable. } 1 \text { if there is a } \\
\text { union affiliated to a political party; } \\
0 \text { if otherwise. }\end{array}$ & 30 & 0.60 & 0.495 \\
\hline INTERNAL & $\begin{array}{l}\text { Dummy variable. } 1 \text { if the union } \\
\text { leadership is internal to the unit; } 0 \\
\text { otherwise. }\end{array}$ & 26 & 0.52 & 0.505 \\
\hline TRIPARTITE & $\begin{array}{l}\text { Dummy variable. } 1 \text { if tri-partite } \\
\text { bargaining takes place; } 0 \\
\text { otherwise }\end{array}$ & 18 & 0.49 & 0.485 \\
\hline PUBLIC & $\begin{array}{l}\text { Dummy variable: } 1 \text { if the } \\
\text { establishment is in the public } \\
\text { sector; } 0 \text { otherwise. }\end{array}$ & 5 & 0.30 & 0.303 \\
\hline
\end{tabular}

Notes: (i) The number of unions and the extent of unionisation are not taken into account, as both of the information are often contested and difficult to verify. (ii) The variable takes one if at least one of the unions present has official party political affiliation, regardless of the party and its political or ideological position. 
Table 3 Pair-wise correlation between the retained dimensions and variables

\begin{tabular}{l|rr}
\hline \multicolumn{1}{c|}{ Variable name } & Dimension 1: & \multicolumn{1}{c}{ Dimension 2: } \\
& Centralisation of LMIs & Internalisation of LMIs \\
\hline UNION & 0.278 & $\mathbf{- 0 . 8 3 9}$ \\
CENTRAL & $\mathbf{0 . 9 3 3}$ & 0.090 \\
PLANT & -0.224 & $\mathbf{- 0 . 8 5 8}$ \\
POLITICAL & 0.673 & -0.555 \\
INTERNAL & -0.485 & $\mathbf{- 0 . 7 8 6}$ \\
TRIPARTITE & $\mathbf{0 . 9 1 0}$ & -0.139 \\
PUBLIC & 0.564 & 0.000 \\
\hline
\end{tabular}

Note: Classical multidimensional scaling (binary dissimilarity measure) with $n=50$, seven variables, and two retained dimensions. Mardia fit measure $1=0.7860$ and measure $2=0.9643$.

Figure 2 MDS mapping of types of LMIs in surveyed units, 2001 to 2013-14

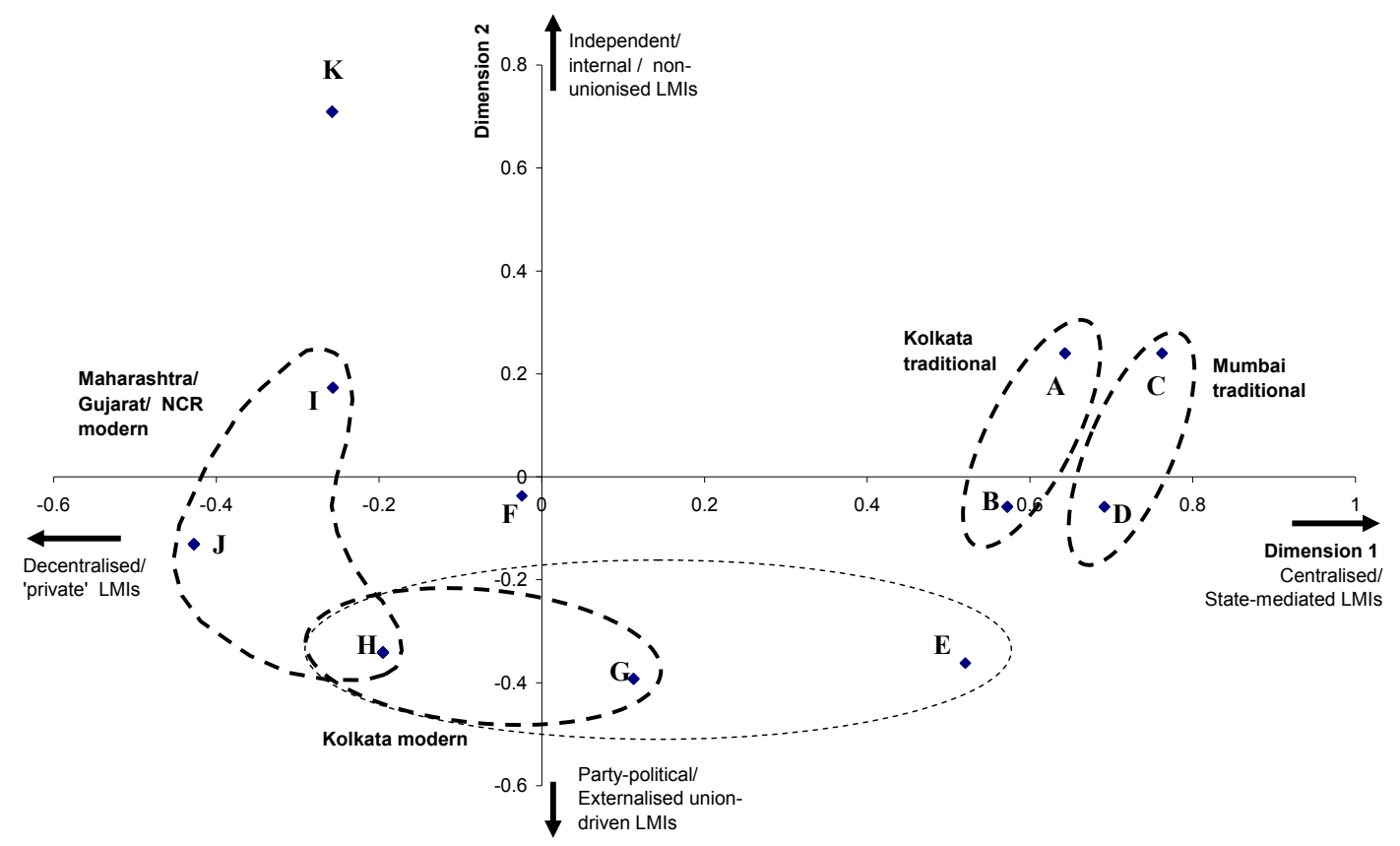


Table 4 Types of LMIs represented by each points on the MDS mapping

\begin{tabular}{|c|c|c|c|c|c|c|c|}
\hline & Unionisation & $\begin{array}{l}\text { Centralised } \\
\text { bargaining } \\
\text { (either at } \\
\text { industry } \\
\text { or/and } \\
\text { region) }\end{array}$ & $\begin{array}{l}\text { Plant-level } \\
\text { bargaining }\end{array}$ & $\begin{array}{l}\text { Politically } \\
\text { affiliated } \\
\text { unions }\end{array}$ & $\begin{array}{l}\text { Internal } \\
\text { union } \\
\text { leadership }\end{array}$ & $\begin{array}{l}\text { Tripartite } \\
\text { collective } \\
\text { bargaining }\end{array}$ & $\begin{array}{c}\text { Ownership } \\
\text { of unit }\end{array}$ \\
\hline A & Yes & Yes & No & Yes & No & Yes & Private \\
\hline B & Yes & Yes & Yes & Yes & No & Yes & Private \\
\hline $\mathrm{C}$ & Yes & Yes & No & Yes & No & Yes & Public \\
\hline D & Yes & Yes & Yes & Yes & No & Yes & Public \\
\hline $\mathrm{E}$ & Yes & Yes & Yes & Yes & Yes & Yes & Public \\
\hline $\mathrm{F}$ & Yes & No & Yes & Yes & Yes & Yes & Private \\
\hline $\mathrm{G}$ & Yes & No & Yes & No & No & No & Private \\
\hline $\mathrm{H}$ & Yes & No & Yes & Yes & Yes & No & Private \\
\hline I & Yes & No & Yes & No & No & No & Private \\
\hline $\mathrm{J}$ & Yes & No & Yes & No & Yes & No & Private \\
\hline K & No & No & No & No & No & No & Private \\
\hline
\end{tabular}


Table 5 Changes to institutional forms and their trajectories in surveyed units

\begin{tabular}{lllll}
\hline & & \multicolumn{2}{l}{ Trajectory of formal changes to } \\
& Institutional change prompted by: & LMIs: & \\
\hline MT4 & Breakdown of extra-unit bargaining & A-D * & $\rightarrow$ I & \\
MT5 $\rightarrow$ GT1 & Breakdown of extra-unit bargaining/ relocation & A-D & $\rightarrow$ F & $\rightarrow$ K \\
KM5/ MM3 $\rightarrow$ GM1 & Relocation/ unionisation & G & $\rightarrow$ K & $\rightarrow$ J \\
KM6 & Privatisation & E & $\rightarrow$ G & \\
KM10 $\rightarrow$ NM4 & Relocation & K & $\rightarrow \mathrm{H}$ & $\rightarrow$ K \\
MM4 & Industrial disputes & F & $\rightarrow$ I & $\rightarrow$ H \\
MM5 $\rightarrow$ MM8/ MM9 & Relocation & J & $\rightarrow$ J / H & \\
MM6 $\rightarrow$ MM10 & Relocation & I & $\rightarrow$ J & \\
NM1 & Unionisation & K & $\rightarrow \mathrm{H}$ & \\
NM2 & Unionisation & K & $\rightarrow \mathrm{J}$ & \\
\hline
\end{tabular}

Note: "A-D indicates the 'cluster' in Figure 2 representing forms of LMIs in the 'traditional' sector; for legend of institutional forms, see Table 4 . 